\title{
Growth hormone response to TRH in male broiler chickens selected for body weight gain or food conversion and reared at either a moderate or a high ambient temperature
}

\author{
$M$ Herremans 1, J Buyse 1, FR Leenstra 2, \\ G Beuving 2, L Berghman 3, E Decuypere 1
}

\author{
1 Laboratory for Physiology and Immunology of Domestic Animals, \\ Kardinaal Mercierlaan 92, 3001 Heverlee, Belgium; \\ 2 Centre for Poultry Research and Information Services Het Spelderholt, \\ 7361 DA Beekbergen, The Netherlands; \\ ${ }^{3}$ Laboratory for Neuroendocrinology and Immunological Biotechnology, \\ Naamsestraat 59, 3000 Leuven, Belgium
}

(Received 19 November 1991; accepted 14 February 1992)

\begin{abstract}
Summary - The aim of the present experiment was to study the growth hormone (GH) response upon thyrotropin releasing hormone (TRH) challenge $(2 \mu \mathrm{g} / \mathrm{kg}$ body weight) in broiler chickens selected for body weight gain (GL line: fat line) or for feed efficiency ( $F C$ line: lean line) reared at either a moderate $\left(33-23^{\circ} \mathrm{C}\right)$ or high $\left(33^{\circ} \mathrm{C}\right)$ ambient temperature. A higher plasma GH level at 5 min after $\mathrm{TRH}$ administration was observed in the high temperature conditioned chickens of both lines. Also at high ambient temperature, an enhanced GH decrease between $15 \mathrm{~min}$ and $30 \mathrm{~min}$ post-injection and a higher acute elimination rate was calculated compared to moderate ambient temperature. A significantly higher $\mathrm{GH}$ secretory response was observed in the leaner FC line chickens, which was probably related to the more pronounced pulsatory $\mathrm{GH}$ secretion rate in these chickens. There was no difference in $\mathrm{GH}$ acute elimination rate between both lines in both environments. No interactions between line and rearing temperature for these parameters of GH dynamics were observed.
\end{abstract}

TRH administration / plasma GH elimination / ambient temperature / lean broiler / fat broiler

Résumé - Réponse de GH à une injection de TRH chez les poulets de chair sélectionnés pour leur croissance ou leur capacité de conversion alimentaire et élevés à température forte ou modérée. Le but de cette expérience était d'étudier la réponse de l'hormone de croissance (GH) à une stimulation par l'hormone provoquant la sécrétion de thyrotropine (TRH) chez des poulets de chair. Les animaux provenaient de lignées sélectionnées en vue d'une croissance rapide (lignée GL ou lignée grasse) ou bien d'un taux élevé de conversion alimentaire (lignée FC ou lignée maigre). Ils ont été entretenus, soit à température ambiante élevée $\left(33^{\circ} \mathrm{C}\right)$, soit à température moyenne $\left(33^{\circ}-\right.$ $23^{\circ} \mathrm{C}$ ). Nous avons observé un niveau de $\mathrm{GH}$ plus élevé dans le plasma 5 min après l'administration 
de TRH dans les 2 lignées de poulets élevés dans un environnement chaud comparé à l'environnement moyen. De même, nos calculs ont montré un déclin du niveau de GH plus prononcé et un taux d'élimination par unité de temps plus rapide entre 15 et 30 min après l'injection chez les poulets maintenus à température élevée. La hausse de sécrétion de GH après stimulation a été significativement plus élevée chez les poussins de la lignée FC, ceux-ci montrant d'ailleurs un niveau spontané des pulsations sécrétrices de GH de plus grande amplitude que ceux de la lignée GL. Nous n'avons pas trouvé de différence dans le taux d'élimination de GH selon les lignées dans les 2 conditions d'environnement. II n'y a pas d'interaction entre l'effet de la lignée et celui de la température d'élevage pour ces paramètres concernant la dynamique de $\mathrm{GH}$.

\section{administration de TRH / taux d'élimination de $\mathrm{GH}$ / température ambiante / poulet de chair maigre et gras}

\section{INTRODUCTION}

It has been well established that thyrotropin releasing hormone (TRH) is a potent growth hormone $(\mathrm{GH})$ secretagogue in young chickens (Harvey and Scanes, 1984) and it may well be the principal endogenous stimulatory releasing factor in chickens since passive immunization with anti-TRH suppressed GH secretion (Klandorf et al, 1985). The episodic nature of $\mathrm{GH}$ secretion has been described both in laying (Buonomo et al, 1984) and meattype (Vasilatos-Younken and Leach, 1986) chickens, as well as in broiler lines divergently selected for body weight gain (GL line) or food conversion (FC line) (Leenstra and Pit, 1988) where the latter showed a peak amplitude almost twice the value of that in the GL line (Decuypere et al, 1991). To our knowledge, the influence of environmental temperature on $\mathrm{GH}$ pulses or $\mathrm{GH}$ response to $\mathrm{TRH}$ is not yet known. However, in vivo $\mathrm{GH}$ response of immature birds to $\mathrm{TRH}$ and $\mathrm{GH}$ releasing factor (GRF) was suppressed by administering $T_{3}$ while systemic administration of $\mathrm{T}_{3}$ was followed by a downregulation of pituitary TRH binding sites (Harvey et al, 1991). Since temperature changes thyroid hormone levels (Decuypere and Kühn, 1988) and $\mathrm{T}_{4}$ turnover rate (Kühn et al, 1984), a changed interaction of the thyro- tropic-somatotropic axis may result in an altered $\mathrm{GH}$ response to TRH. Because the divergently selected broiler lines showed marked differences in $\mathrm{GH}$ levels and in $\mathrm{GH}$ pulse amplitudes, the effect of temperature on TRH induced $\mathrm{GH}$ increase was studied in both lines.

\section{MATERIAL AND METHODS}

Four-week-old male broiler chickens from the $\mathrm{GL}$ and FC lines were used. The history of these selection lines has been reported by Leenstra and Pit (1988) and production characteristics have been extensively described elsewhere (Leenstra et al, 1991). Endogenous GH was stimulated indirectly by a single injection of TRH ( $2 \mu \mathrm{g}$ per $\mathrm{kg}$ body weight: purchased from Sigma, St Louis, MO, USA) in a brachial arterial cannula of fed conscious animals. Blood samples $(0.3 \mathrm{ml})$ were collected just before TRH injection and $5,15,30$ and $60 \mathrm{~min}$ thereafter. Birds of both lines were reared either in a hot (constant $33^{\circ} \mathrm{C}$ ) or a moderate (step-down from 33 to $23^{\circ} \mathrm{C}$ over a 4-week period) environment. This resulted in a 2-factorial model (genotypetemperature) the final animal number being: $G L$ moderate $=11 ; \mathrm{Gl}$ hot $=10 ; \mathrm{FC}$ moderate $=9$; $\mathrm{FC}$ hot $=14$.

\section{GH assay}

Blood samples were collected in heparinized tubes, centrifuged, and plasma stored at $-18^{\circ} \mathrm{C}$ 
prior to $\mathrm{CGH}$ determination with a homologous radioimmunoassay (Berghman et al, 1988). Affinity-purified $\mathrm{CGH}$ was iodinated using the chloramine $T$ method (Greenwood et al, 1963). Twenty $\mu$ l sample or standard GH $(2-2 C 0 \mathrm{ng} / \mathrm{ml})$ was incubated for $24 \mathrm{~h}$ with $100 \mu \mathrm{l}$ mouse monoclonal GH antibody (1/2-106 ascites) and $100 \mu \mathrm{l}$ tracer. After adding $50 \mu \mathrm{l}$ goat antimouse antiserum (1/40 dilution) a second $24-h$ incubation period followed. After centrifugation at $2400 \mathrm{~g}$ for $10 \mathrm{~min}$, the supernatant was aspirated and the precipitate was counted in a Q-counter. The system detection limit was $2 \mathrm{ng} / \mathrm{ml}$ and no cross-reactivity with other pituitary hormones was observed. The intra- and inter-assay variation coefficient was 4 and $15.5 \%$ respectively. Good parallelism between standard and plasma dilution curves was obtained. For determination of peak levels, dilution series were needed to meet the standard curve of the assay. Interdilution variability within the assay, however, was sometimes very high (up to 60\%). The mean values for $\mathrm{GH}$ in dilution series, which generally fitted the disappearance curve more closely, were used in these cases.

\section{Statistical analysis}

Statistical differences between measured or calculated parameters were revealed by parametric (ANOVA or MANOVA) or non-parametric statistics (Bartlett test or Mann-Whitney U-test) where appropriate. Comparison of groups of curves from individual birds was made by analysis of variance after transformation of the time series data of individual birds into orthogonal polynomials (GLM, repeated measurements with polynomials: SAS, 1986). Alternatively, the coefficients of the curves that were fitted to the individual data were used as a new data set, which was then compared between groups by a multivariate analysis of variance (MANOVA). Visual illustration of maximal differences between groups resulted from multivariate canonical discriminant analysis (CANDISC: SAS, 1986) on the new matrix with the coefficients of the curves as new data. Although the canonical procedure is usually applied to evaluate complex multivariate data matrices, here it was only used to obtain an optimal rotation of the picture. Acute elimination rates were calculated as the differential of the curve that fitted the hormone- disappearance data. This variable represents the slope of the tangent line to the curve at each point, and thus the steepness of the direction the curve is taking. Curve fitting also followed an exponential approach $\left(\left(\mathrm{GH}(\mathrm{ng} / \mathrm{ml})=a e^{-b \text {.time })}\right)\right.$ and the half-life was calculated as In $(0.5 / b)$. Curve fittings and calculations used the data of individual birds as entries without correction for extrapolated baseline values.

\section{RESULTS}

TRH-induced $\mathrm{GH}$ release in both lines and environments is shown in figure 1.

The increase in plasma GH levels following TRH injection was characterized by the difference in $\mathrm{GH}$ at 5 min post-injection minus the value noted immediately before injection (table I). This increase was significantly different according to line ( $F C>G L$; $F_{40}=6.22, P=0.014$ ) and the effect of temperature was even more manifest (hot $>$ moderate; $F_{40}^{1}=8.9, P=0.005$ ). There was no line $x$ temperature interaction $\left(F_{40}{ }^{1}=0.47, P=0.5\right)$, and no effect of the pre-injection value (pre-value as a covariable did not influence ANOVA results). Only 4 post-injection data points represent a rather poor picture for curve fitting and time pattern evaluation. Nevertheless, the obvious time pattern of $\mathrm{GH}$ disappearance

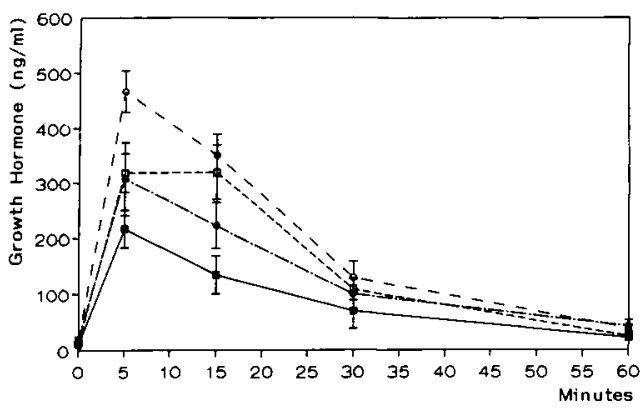

Fig 1. $\mathrm{TRH}$-induced $\mathrm{GH}$ responses according to line (GL or $\mathrm{FC}$ ) and temperature (GL $33^{\circ} \mathrm{C}, \square$ $\mathrm{GL} 23^{\circ} \mathrm{C} \mathrm{E}, \mathrm{FC} 33^{\circ} \mathrm{C} \mathrm{O}, \mathrm{FC} 23^{\circ} \mathrm{C}$ ). Time $0=$ injection of TRH. 
Table I. TRH induced GH ( $\mathrm{ng} / \mathrm{ml}$ ) increases (difference between concentration before injection and $5 \mathrm{~min}$ after) in 2 lines of chickens at 2 temperatures.

\begin{tabular}{lll}
$\begin{array}{l}\text { Temperature } \\
\left({ }^{\circ} \mathrm{C}\right)\end{array}$ & GL line & FC line \\
\hline 23 & $206 \pm 43.2(11)$ & $289 \pm 47.8(9)$ \\
33 & $307 \pm 45.4(10)$ & $450 \pm 38.3(14)$
\end{tabular}

Values are means \pm SEM. ( ) : No of chickens. Line effect $P=0.014$; temperature effect $P=0.005$; no interaction.

was hichly significant $\left(F_{36}{ }^{3}=19.8, P<\right.$ 0.000 1). There was an effect of line (ANOVA with polynomials covaried for pre-value: $F_{38}^{1}=4.3, P<0.05$ ), and also particularly of temperature $\left(F_{38}^{1}=11.8\right.$, $P<0.002)$. There was also a significant interaction of time $x$ temperature $\left(F_{36}{ }^{3}=5.2\right.$, $P<0.005$ ) which represents a temperature-dependent difference in the GH disappearance pattern. The hot environment resulted in a higher response of $\mathrm{GH}$, but subsequently in a much steeper decline. There was a highly significant temperature effect on the decrease in $\mathrm{GH}$ levels between 15 and 30 minutes post-injection (table II: 2-factor ANOVA: $F_{39}^{3}=11, P=$
Table II. GH decrease $(\mathrm{ng} / \mathrm{ml})$ according to temperature and line between 15 and $30 \mathrm{~min}$ following $\mathrm{TRH}$ injection.

\begin{tabular}{lrl}
$\begin{array}{l}\text { Temperature } \\
\left({ }^{\circ} \mathrm{C}\right)\end{array}$ & GL line & FC line \\
\hline 23 & $64 \pm 25(11)$ & $113 \pm 26(9)$ \\
33 & $207 \pm 48(10)$ & $223 \pm 42(14)$
\end{tabular}

Values are means \pm SEM. ( ) : No of chickens. Temperature effect : $P=0.002$.

0.002 ; hot $>$ moderate). There was no significant effect of line or of line $x$ temperature on this aspect of GH decrease. When the 2 coefficients of the individual exponential curves (table III) were compared in a $2 \times 2$ factor multivariate ANOVA, similar general conclusions about the hormone disappearance were obtained. The effect of temperature was more important (Wilks' Lambda: $\left.0.76, F_{39}^{2}=6.2, P<0.005\right)$ than the effect of line (Wilks' Lambda $=0.84$, $\left.F_{39}^{2}=3.6, P<0.05\right)$ and there was no line $x$ temperature interaction (Wilks' Lambda $=$ $\left.0.93, F_{93}^{2}=1.4, P=0.3\right)$. However, because there was a significant effect of line and temperature only on the a-coefficient of

Table III. Curve characteristics (mean \pm SEM) of the exponential fitting $((\mathrm{GH}(\mathrm{ng}(\mathrm{ng} / \mathrm{ml})=a e-$ b.time) $)$ ).

\begin{tabular}{lccccc}
\hline & \multicolumn{3}{c}{ GL line } & & \multicolumn{2}{c}{$F C$ line } \\
\cline { 2 - 3 } \cline { 5 - 6 } \cline { 5 - 6 } & $23{ }^{\circ} \mathrm{C}$ & $33^{\circ} \mathrm{C}$ & & $2{ }^{\circ} \mathrm{C}$ & $3{ }^{\circ} \mathrm{C}$ \\
\hline & & & & \\
a birds & 11 & 10 & & 9 & 14 \\
a-Coefficient & $307 \pm 50$ & $436 \pm 50$ & & $416 \pm 95$ & $645 \pm 57$ \\
$r^{2}$ & $-0.062 \pm 0.007$ & $-0.041 \pm 0.004$ & & $-0.048 \pm 0.010$ & $-0.051 \pm 0.007$ \\
& $0.973 \pm 0.011$ & $0.953 \pm 0.013$ & & $0.977 \pm 0.007$ & $0.965 \pm 0.013$ \\
\hline
\end{tabular}

Significant effect of temperature $(P<0.005)$ and line $(P<0.05)$ on a-coefficient but not on $b$-coefficient. 
the exponential fittings, there was no significant difference according to line or temperature in the half-lives deduced from the exponentials (Kruskal-Wallis, $P=0.13$ ). Acute elimination rates, calculated as the differential of the second power polynomial fitted to the hormone disappearance data of individuals, did not differ according to line (ANOVA, Wilks' Lambda $=0.90, F_{39}{ }^{2}=$ 2.25, $P=0.12$ ) but showed and effect of temperature (MANOVA, Wilks' Lambda $=$ $0.72, F_{39}{ }^{2}=7.7, P<0.002$ ). There was no line $x$ temperature interaction. These differences can be illustrated by plotting the $2 \mathrm{co}$ efficients of the differentials of the individual curves (fig 2), but visualization of the significant effects can be optimized by a canonical discriminant procedure, which maximizes the differences between groups (fig 3).

\section{DISCUSSION}

Although temperature by itself hardly showed any effect on pre-injection $\mathrm{GH}$ val-

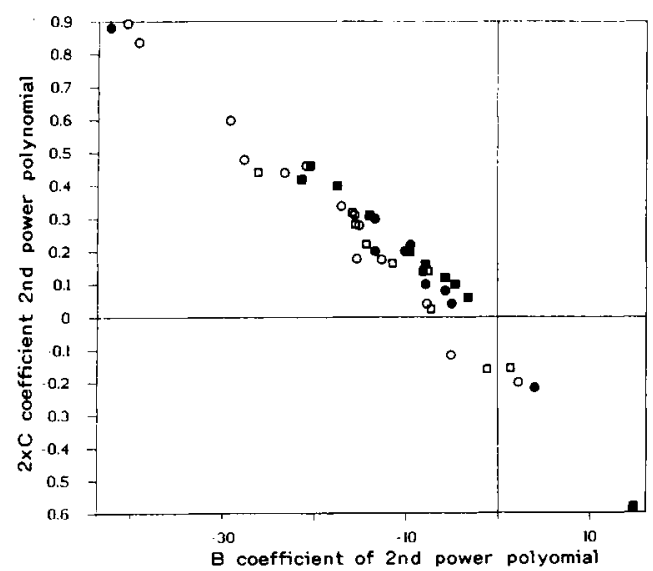

Fig 2. Characteristics of the acute elimination rate curves in individual birds (coefficients of the differential of the 2nd power polynomial) according to line (GL or FC) and temperature (GL $33^{\circ} \mathrm{C} \square, \mathrm{GL} 23^{\circ} \mathrm{Ca}, \mathrm{FC} 33^{\circ} \mathrm{C} \mathrm{O}, \mathrm{FC} 23^{\circ} \mathrm{C} O$ ).

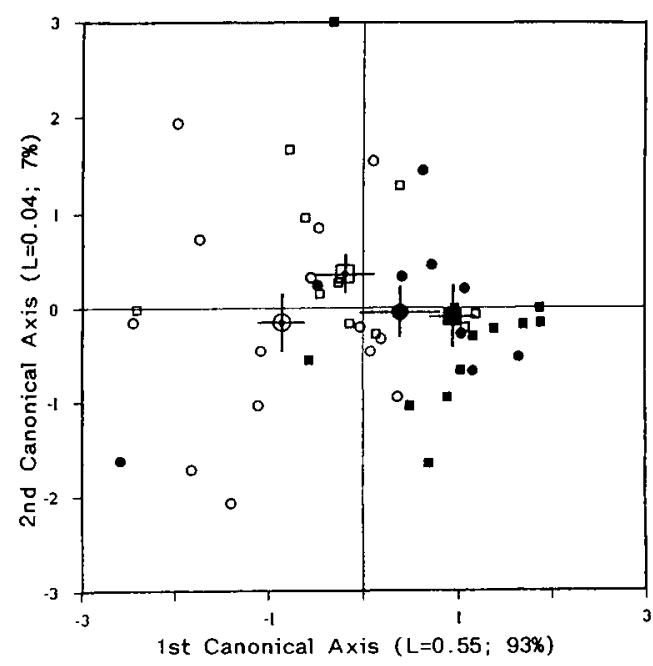

Fig 3. Optimized visual difference by canonical discrimination of the data on TRH-induced $\mathrm{GH}$ response. Group means (larger symbols) \pm SEM and individual birds shown: $\mathrm{GL} 33^{\circ} \mathrm{C} \square, \mathrm{GL}$ $23^{\circ} \mathrm{C} \mathrm{D}, \mathrm{FC} 33^{\circ} \mathrm{C} \mathrm{O}, \mathrm{FC} 23^{\circ} \mathrm{C} \bullet$

ues, high temperature enhanced both the $\mathrm{GH}$ secretory response to TRH and the $\mathrm{GH}$ clearance. The increased magnitude of GH peak following TRH administration at the higher temperature may be explicable in terms of the depressive effects of thyroid hormones on $\mathrm{GH}$ secretion (Harvey, 1983; Harvey et al, 1990, 1991) while the thyroid function is known to be reduced in warmer environments (Decuypere et al, 1981; Kühn et al, 1984). The reduced thyroid function may then result in an enhanced sensitivity of $\mathrm{GH}$ to a secretagogue challenge such as TRH (Harvey et al, 1990). The enhanced $\mathrm{GH}$ decrease between 15 and 30 minutes after a similar TRH injection in the high temperature conditioned animals should be interpreted carefully.

It may be interpreted as a shorter secretagogue challenge, due to a hypothetical shorter half-life of TRH in high tempera- 
ture reared chicks, or to an increased elimination of $\mathrm{GH}$. The first possibility is rather unlikely in view of the higher $\mathrm{GH}$ peak values obtained after TRH linked with a reduced thyroid function on a TRH challenge. From the higher decrease in $\mathrm{GH}$ levels at a specific time interval and the acute elimination rates calculated as the differential from the individual hormone disappearance curves, the second possibility seems valid. Nevertheless the half-life, characterized by the $b$-coefficient of the indvidual exponential curves, was not different between lines or temperature groups.

A higher $\mathrm{GH}$ secretory response to $\mathrm{TRH}$ was observed in the FC line, which may be linked to the higher endogenous pulsatility found in this line (Decuypere et al, 1991). Experimentally induced or natural $\mathrm{GH}$ pulses have been found to be related to leanness and better feed efficiency in chickens (Johnson et al, 1986, 1987; Vasilatos-Younken et al, 1988; Decuypere et al, 1991), while genetically lean and fat sheep differ in their $\mathrm{GH}$ response to GRF (Sutti et al, 1991). The mechanisms responsible for the differences in $\mathrm{CGH}$ response to TRH between lean and fat broiler lines have still to be elucidated. They may involve a lower TRH responsiveness and/or a lower availability of pituitary store of $\mathrm{cGH}$ in the GL line. In contrast to the higher rate of $\mathrm{GH}$ clearance in fat compared to lean sheep, inversely related to the $\mathrm{GH}$ relesed by GRF (Suttie et al, 1991), no differences were found either in $\mathrm{GH}$ decrease between both chicken lines in the interval between 15 and 30 minutes after the TRH challenge, or in the calculated acute elimination rates as can be seen in figures 2 and 3 . The effect of temperature was unrelated to the line effect both as far as $\mathrm{GH}$ response to $\mathrm{TRH}$ and $\mathrm{GH}$ disappearance were concerned, since a line $x$ temperature interaction was never observed. Both temperature and line data indicate the physiological unrelatedness of the amplitude of $\mathrm{GH}$ pulses or $\mathrm{GH}$ responses upon TRH with the GH disappearance or elimination rate. Our data confirm the earlier findings of Pethes et al (1979) in ducks showing a reduced plasma $\mathrm{GH}$ response to TRH in cold $\left(10^{\circ} \mathrm{C}\right)$ adapted animals; however, this is the first time that it has been shown in divergently selected chicken lines kept under 2 different temperature schemes.

\section{ACKNOWLEDGMENTS}

The authors are grateful for the financial support of NATO (Grant No 8501-8007), and that provided by KU Leuven (OT/89/20). M Herremans and $L$ Berghman were supported by the National Fund for Scientific Research.

\section{REFERENCES}

Berghman L, Van Beeumen J, Decuypere E, Kühn ER, Vandesande F (1988) One-step purification of chicken growth hormone from a crude pituitary extract by use of a monoclonal immunoadsorbent. J Endocrinol 118, 381-387

Buonomo FC, Lauterio TJ, Scanes CG (1984) Episodic growth hormone secretion in the domestic fowl (Gallus domesticus): $\alpha$ adrenergic regulation. Comp Biochem Physiol $78 \mathrm{C}, 409-413$

Decuypere E, Kühn ER (1988) Alterations in thyroid hormone physiology induced by temperature and feeding in newly hatched chickens. Acta Physiol Pol 39, 380-394

Decuypere $E$, Hermans SC, Michels $H$, Kühn $E R$, Verheyen J (1981) Thermoregulatory response and thyroid hormone concentrations after cold exposure of young chicks treated with iopanoic acid or saline. Adv Physiol Sci 33, 291-298

Decuypere $E$, Leenstra F, Buyse J, Beuving G, Berghman $L$ (1991) Temporal secretory patterns of growth hormone in male meat-type chickens of lines selected for body weight 
gain or food conversion. Br Poult Sci 32, 1121-1128

Greenwood FC, Hunter WM, Glover JS (1963) The preparation of 131 l-labelled human growth hormone of high specific radioactivity. Biochem J 89, 114-123

Harvey S (1983) Thyroid hormones inhibit growth hormone secretion in domestic fowl (Gallus domesticus). J Endocrinol 96, 329334

Harvey S, Scanes CG (1984) Comparative stimulation of growth hormone secretion in anaesthetized chickens by human pancreatic growth hormone releasing factor (hp GRF) and thyrotropin-releasing hormone. Neuroendocrinoly $39,314-320$

Harvey S, Klandorf H, Scanes CG (1990) Participation of tri-iodothyronine and metabolic clearance rate in the inhibition of growth hormone secretion in thyroxin-treated domestic fowl. J Endocrinol 124, 215-223

Harvey S, Decuypere E, Darras VM, Berghman $L$ (1991) Differential effects of $T_{4}$ and $T_{3}$ on TRH- and GRF-induced GH secretion in the domestic fowl. Reprod Nutr Dev 31, 451-460

Johnson RJ, Tomas F, Pym R, Fairclough R (1986) The effect of long-term genetic selection on growth hormone secretion and protein turnover in meat-type chickens. Proc 7th Eur Poult Conf, 975-979

Johnson RJ, Fairclough R, Cahill LP (1987) Temporal secretory pattern of growth hormone in young meat-type poultry. Br Poult Sci 28, 103-111

Klandorf H, Harvey S, Fraser HM (1985) Physiological control of growth hormone secretion by thyrotropin-releasing hormone in the domestic fowl. J Endocrinol 105, 351-355

Kühn ER, Decuypere E, Rudas P (1984) Hormonal and environmental interactions on thyroid function in the chick embryo and posthatching chicken. $J$ Exp Zool 232, 653-658

Leenstra FR, Pit R (1988) Consequences of selection for feed conversion in broiler chickens. In: Advances in Animal Breeding (Korver $\mathrm{S}$ et al, eds) Pudoc, Wageningen, 160-161

Leenstra FR, Decuypere E, Beuving G, Buyse J, Berghman L, Herremans M (1991) Concentrations of hormones, glucose, triglycerides and free fatty acids in the plasma of broiler chickens selected for weight gain or food conversion. Br Poult Sci 32, 619-632

Pethes C, Scanes CG, Rudas P (1979) Effect of synthetic thyrotropin releasing hormone on the circulating growth hormone concentration in cold and heat stressed ducks. Acta Vet Acad Sci Hung 27, 175-177

Suttie JM, Lord EA, Gluckman PD, Fennessy PF, Littlejohn RP (1991) Genetically lean and fat sheep differ in their growth hormone response to growth hormone releasing factor. Dom Anim Endocrinol 8(2), 323-329

Vasilatos-Younken R, Leach RM (1986) Episodic patterns of growth hormone secretion and growth hormone status of normal and dyschondroplastic broiler chickens. Growth 50, 84-94

Vasilatos-Younken $R$, Cravener TL, Cogburn LA, Mast MG, Wellenreiter RH (1988) Effect of pattern of administration on the response to exogenous pituitary-derived chicken growth hormone by broiler-strain pullets. Gen Comp Endocrinol 71, 268-283 